\title{
Some coagulase negative Staphylococcus spp. isolated from buffalo can be misidentified as Staphylococcus aureus by phenotypic and Sa442 PCR methods
}

\author{
Camila C. de Almeida ${ }^{1,3}$, Lucas J. L. Pizauro ${ }^{2,3}$, Glenn A. Soltes ${ }^{3}$, Durda Slavic ${ }^{4}$, Fernando A. de Ávila²,
} João M. Pizauro ${ }^{5}$ and Janet I. Maclnnes ${ }^{3^{*}}$ (1)

\begin{abstract}
Objective: Staphylococcus aureus is a commonly reported cause of buffalo mastitis. However, its prevalence may be overestimated. The aim of this study was to compare S. aureus identification by conventional phenotypic and genotypic assays versus Matrix-Assisted Laser Desorption Ionization-Time of Flight Mass Spectrometry (MALDI-TOF MS) and novel real-time quantitative PCR tests for the cytochrome oxidase subunit D II (cydB) and staphylocoagulase (coa) genes.

Results: From 408 samples obtained from buffalo milk/milking environment, 32 putative $S$. aureus strains were identified based on characteristic growth on Baird Parker agar, positive catalase reaction, ability to clot rabbit plasma, and positive Sa442 PCR assay. However, in further testing, only 10 of these strains were positive in latex agglutination tests and by MALDI-TOF MS, only eight of the 32 strains were S. aureus while the rest were S. chromogenes (19), S. agnetis (3), S. cohnii (1), or S. xylosus (1). All eight strains identified as S. aureus by MALDI-TOF analysis and confirmed by $16 \mathrm{~S}$ RNA gene sequencing were positive in a $S$. aureus-specific cydB PCR test. As well, $7 / 8 \mathrm{~S}$. aureus strains were PCR positive in a real-time coa PCR test as were 2/69 S. chromogenes and the lone $S$. xylosus strain tested.
\end{abstract}

Keywords: Mastitis, Staphylococcus aureus, Species-specific PCR tests, cydB PCR

\section{Introduction}

Buffalo milk and its derivatives have become increasingly important worldwide [1] and Staphylococcus aureus is one of the most significant pathogens responsible for contagious mastitis in dairy buffaloes [2]. Antibiotic treatment of $S$. aureus mastitis is often unsuccessful and treatment failures can lead to spread of the infection. As a result, animals with chronic $S$. aureus infection are often culled [3].

The initial identification of $S$. aureus is based on culture and phenotype on specific media; other assays commonly

\footnotetext{
*Correspondence: macinnes@uoguelph.ca

${ }^{3}$ Department of Pathobiology, University of Guelph, 50 Stone Rd. East, Guelph, ON N1G 2W1, Canada

Full list of author information is available at the end of the article
}

used to identify S. aureus are the Sa442 PCR, nuc gene PCR, and latex agglutination tests. The Sa442 PCR test, developed by Martineau et al. [4] targets a chromosomal DNA fragment thought to be specific for S. aureus, the nuc gene encodes a species-specific thermonuclease, while commercially available latex agglutination kits such as the Staphaurex latex test are based on the interaction of $S$. aureus surface-anchored proteins with human IgG and fibrinogen bound to latex particles [5]. However, these tests may not be accurate and can lead to erroneous identification, and in turn, to unnecessary culling [5, 6]. Here we describe how common testing approaches can lead to misidentification of "non-S. aureus" strains as $S$. aureus and the development of new a $c y d B$ realtime PCR assay that can be used for accurate $S$. aureus identification. 


\section{Main text \\ Methods \\ Sample collection}

Milk samples $(\mathrm{n}=320)$ were collected from 80 randomly selected female buffaloes from a private dairy farm located in Sao Paulo State, Brazil from November 2013 to April 2014. After physical examination of the mammary glands [7], teats were cleaned with $70 \%$ alcohol and milk from each quarter was evaluated by strip cup and California mastitis tests [8]. Hand samples from 16 consenting milkers and 64 samples from liners were collected using sterile swabs (Pro-Lab Diagnostics) and stored in peptone water as described previously [9].

\section{CoPS isolation and identification}

Isolation and identification of $S$. aureus was done according to compendium of methods for the microbiological examination of foods [10]. Strains with positive egg yolk reactions [11] were tested for Gram and catalase reactions, haemolytic activity, and ability to clot rabbit plasma using a Coagu-Plasma kit (Laborclin, Pinhais, Brazil) according to manufacturer's instructions with $S$. aureus ATCC 25293 and S. epidermidis ATCC 12228 as the positive and negative controls respectively. In addition, isolates were tested with the Staphyclin latex test (Laborclin, Pinhais, Brazil) according to the manufacturer's instructions.

\section{DNA extraction}

For DNA extraction, well-isolated colonies were inoculated into $\mathrm{BHI}$ broth, incubated at $37{ }^{\circ} \mathrm{C}$ for $18 \mathrm{~h}$ and extracted according to the method of Kuramae-Izioka [12] with minor modifications as described previously [13].

\section{Sa442 detection}

Isolates were characterized using the PCR assay of Martineau et al. [4] with minor modifications. PCR primers (Table 1 ) were used at $10 \mathrm{pmol} / \mu \mathrm{L}$ in $25 \mu \mathrm{L}$ reaction mixtures with $50 \mathrm{ng} / \mu \mathrm{L}$ of DNA and $20 \mu \mathrm{L}$ LightCycler ${ }^{\circledR}$ 480 SYBER Green Master mix (Roche Diagnostics,
Indianapolis, IN). Amplification parameters were: one cycle at $95{ }^{\circ} \mathrm{C}$ for $10 \mathrm{~min}$, followed by 40 cycles at $95{ }^{\circ} \mathrm{C}$ for $10 \mathrm{~s}, 55{ }^{\circ} \mathrm{C}$ for $20 \mathrm{~s}$, and $72{ }^{\circ} \mathrm{C}$ for $12 \mathrm{~s}$ in a Roche LightCycler $^{\circledR} 480$ (LC480) thermocycler. The ramp rates were $4.4,2.2$, and $4.4{ }^{\circ} \mathrm{C} / \mathrm{s}$, respectively. Staphylococcus chromogenes and Streptococcus suis DNAs and water were used in negative control reactions and $S$. aureus strains COL, NewMan, MW2, Mu50 and ATCC 25923 were used as positive controls. A melting step $\left(62^{\circ} \mathrm{C}\right)$ was done to confirm single product.

\section{Matrix-Assisted Laser Desorption Ionization-Time of Flight Mass Spectrometry (MALDI-TOF MS)}

Identification of putative Staphylococcus aureus strains was done using a MALDI Bruker Biotyper system (Bruker Daltonics Inc., Billerica, MA, USA) at the Animal Health Laboratory, University of Guelph, Guelph, Ontario, Canada, as described previously [13].

\section{S rRNA gene sequencing}

$16 \mathrm{~S}$ rRNA gene sequencing $(\sim 1000 \mathrm{bp})$ was also done at the Animal Health Laboratory and sequences were compared with the 16S rRNA gene of Staphylococcus aureus MCRF184 (CP014791.1) and other Staphylococcus spp. sequences using blastn.

\section{Design of cydB species-specific primers}

PCR primers to the $S$. aureus cydB gene (cytochrome D ubiquinol oxidase subunit II; NCBI accession number NC_007795.1) were designed as described previously [13] and produced a $432 \mathrm{bp}$ amplicon. The amplicons were confirmed by DNA sequencing as described above (Table 1). As well, an additional 84 putative staphylococci from buffalo milk/milking environment were evaluated using the $c y d B$ test [13].

\section{Design of coagulase gene primers}

Published coa primers [14] generate products of different sizes so a new primer pair (coaF and coaR; Table 1) was designed using PrimerQuest software (Integrated DNA

Table 1 Sequence of primers used in PCR assays

\begin{tabular}{|c|c|c|c|c|}
\hline "Gene" & Primer & Sequence $\left(5^{\prime}-3^{\prime}\right)$ & Product (bp) & Reference \\
\hline \multirow[t]{2}{*}{ coa } & Forward & GTCTTGAAAGTAGCTCATCTAAACTTG & 228 & This study \\
\hline & Reverse & ATCCAAATGTTCCATCGTTGTATTC & & \\
\hline \multirow[t]{2}{*}{ cyd-aureus } & Forward & CCCATTTGCTTGGTCTGTAGTA & 432 & This study \\
\hline & Reverse & GTCCAGCCCATTTCTGGATTA & & \\
\hline \multirow[t]{2}{*}{ Sa442 } & Forward & AATCTTTGTCGGTACACGATATTCTTCACG & 108 & Martineau et al. [4] \\
\hline & Reverse & CGTAATGAGATTTCAGTAGATAATACAACA & & \\
\hline
\end{tabular}


technologies, Inc. http://www.idtdna.com) to the coagulase gene of S. aureus JCSC 7638 (AB488509.1). A conserved region of the gene was identified by aligning 103 strains in GenBank using CLC Sequence View 7 software (Additional file 1: Fig. S1).

\section{Real-time PCR}

Real-time PCR primers (Table 1) were used at $10 \mathrm{pmol} /$ $\mu \mathrm{L}$ in $25 \mu \mathrm{L}$ reaction mixtures containing $50 \mathrm{ng} / \mu \mathrm{L}$ of DNA and $20 \mu \mathrm{L}$ Light Cycler 480 (LC480) SYBER Green Master mix (Roche Diagnostics, Indianapolis, IN). For $c y d B$ and coa gene amplifications the parameters were: one cycle at $95{ }^{\circ} \mathrm{C}$ for $10 \mathrm{~min}$, followed by 40 cycles at $95^{\circ} \mathrm{C}$ for $10 \mathrm{~s}, 55^{\circ} \mathrm{C}$ for $20 \mathrm{~s}$, and $72^{\circ} \mathrm{C}$ for $25 \mathrm{~s}$ in a Roche Light Cycler 480 (LC480). Ramp rates were 4.4, 2.2, and $4.4{ }^{\circ} \mathrm{C} / \mathrm{s}$, respectively; Streptococcus suis DNA and water were used as negative controls. In addition, a melting step $\left(62{ }^{\circ} \mathrm{C}\right)$ was done to confirm a single product. $S$. aureus strains COL, NewMan, MW2, Mu50 and ATCC 25923 were used as positive controls. All real-time PCR were performed in triplicate.

\section{Results}

Staphylococcus spp. isolation and preliminary identification

Thirty-two putative $S$. aureus strains were selected based on their characteristic phenotype on Baird Parker agar. These Gram positive strains were catalase positive and were positive in the $S$. aureus species specific Sa442 PCR assay of Martineau et al. [4]. In further testing, 24 samples were consistently positive in the coagulase test; while eight gave at least one discordant result. Also, 21 of the
32 putative $S$. aureus strains were $\beta$-haemolytic, two were $\alpha$-haemolytic and nine were non-haemolytic.

\section{Latex test, identification by MALDI-TOF and 16S rRNA sequencing}

Only ten of the 32 strains gave a positive latex agglutination result and MALDI-TOF MS analysis revealed that only eight of the 32 were $S$. aureus with the remainder being S. chromogenes $(\mathrm{n}=19)$, S. agnetis $(\mathrm{n}=3)$, S. xylosus $(\mathrm{n}=1)$, or $S$. cohnii $(\mathrm{n}=1)$ (Table 2$)$. All eight strains identified as $S$. aureus by MALDI-TOF analysis had $100 \%$ identity with the 16S rRNA gene of Staphylococcus aureus MCRF184 (NZ_CP014791.1). The two latex false positive strains were $S$. agnetis and chromogenes by $16 \mathrm{~S}$ sequencing and MALDI_TOF.

\section{cydB gene analysis and detection}

Alignment of gene sequences (https://www.ncbi.nlm.nih. gov/genbank/) suggested that the $c y d B$ gene is well conserved in Staphylococcus and thus allowed for the design of species-specific primers (Additional file 2: Fig. S2). The eight $S$. aureus isolates were positive for the $S$. aureus-specific $c y d B$ primers and resultant amplicons had 99-100\% identity with $S$. aureus NCTC 8325. Further, the $S$. aureus specific $c y d B$ primers did not amplify any of the other CoPS tested in this study nor the 84 strains of other putative staphylococci evaluated by Pizauro et al. [13].

\section{coa gene analysis}

Alignment of 103 coagulase gene sequences (https:// www.ncbi.nlm.nih.gov/genbank/) revealed that although

Table 2 Comparison of Staphylococcus spp. identification by MALDI-TOF MS and positive rabbit plasma clotting, Sa442 PCR, latex agglutination, coa and S. aureus cydB PCR tests

\begin{tabular}{|c|c|c|c|c|c|c|}
\hline Species & MALDI-TOF MS & Plasma clotting & Sa442 PCR & Latex test & $c y d B$ PCR & coa PCR \\
\hline S. agnetis & 17 & 3 & 3 & 1 & 0 & 0 \\
\hline S. aureus & 8 & 8 & 8 & 8 & 8 & 7 \\
\hline S. caprae ${ }^{a}$ & 1 & 0 & 0 & 0 & 0 & 0 \\
\hline S. equorum ${ }^{a}$ & 3 & 0 & 0 & 0 & 0 & 0 \\
\hline S. epidermidis & 8 & 0 & 0 & 0 & 0 & 0 \\
\hline S. haemolyticus ${ }^{a}$ & 2 & 0 & 0 & 0 & 0 & 0 \\
\hline S. hominis ${ }^{a}$ & 1 & 0 & 0 & 0 & 0 & 0 \\
\hline S. pateuri ${ }^{\mathrm{a}}$ & 2 & 0 & 0 & 0 & 0 & 0 \\
\hline S. saprophyticus ${ }^{a}$ & 1 & 0 & 0 & 0 & 0 & 0 \\
\hline S. sciuri ${ }^{\mathrm{a}}$ & 1 & 0 & 0 & 0 & 0 & 0 \\
\hline S. warneri ${ }^{a}$ & 1 & 0 & 0 & 0 & 0 & 0 \\
\hline S. xylosus & 1 & 1 & 1 & 0 & 0 & 1 \\
\hline S. chromogenes & 69 & 19 & 19 & 1 & 0 & 2 \\
\hline S. cohnii & 1 & 1 & 1 & 0 & 0 & 0 \\
\hline Total & 116 & 32 & 32 & 10 & 8 & 10 \\
\hline
\end{tabular}

a Data from Pizauro et al. [13] 
coa genes possess many polymorphic areas, a region between 1300 and 1600 bp has sufficient homology to be used for detection in S. aureus strains (Table 1, Additional file 1: Fig. S1). All of the $S$. aureus positive control strains tested [COL (NC_002951.2), NewMan (NC_009641.1), MW2 (NC_003923.1), Mu50 (NC_002745.2) and Staphylococcus aureus ATCC (25923)] were positive using the $\operatorname{coa} \mathrm{F}$ and $\operatorname{coa} \mathrm{R}$ primer pair.

\section{Coagulase test and coa gene detection}

Twenty-four strains clotted rabbit plasma (Table 2). Eight strains gave discordant results with at least one negative and one positive. Of these strains, seven of the $S$. aureus $(\mathrm{n}=8)$ and two of the $S$. chromogenes $(\mathrm{n}=19)$ and one $S$. xylosus strain were positive for the coa gene while none of the $S$. agnetis $(\mathrm{n}=3)$ nor the $S$. cohnii were positive for the coa gene. The sequence of the PCR products had $98 \%$ identity with the $S$. aureus coa gene from strain JCSC 7633 (accession number AB488507.1) and 99\% identity with the coa gene in S. aureus strain MW2 genome (accession number BA000033.2).

\section{Discussion}

A number of typically coagulase negative Staphylococcus spp. including more than a quarter of $S$. chromogenes isolates (19/69) and at least some $S$. xylosus (1/1), S. cohnii $(1 / 1)$, and $S$. agnetis (3/17) were coagulase positive. This finding is consistent with studies of Santos et al. [15] in which 23/42 CoNS strains clotted rabbit plasma. These authors suggested that this phenotype was related to specific PFGE-types, but not with the clumping factor test. The presence of coagulase is an indicator of pathogenicity since it enables bacteria to resist phagocytosis and cause chronic infections [16]. Host specific adaptations can be acquired though mobile genetic elements (MGEs) [16, 17] from nearby S. aureus [16] or other CoPS such as $S$. pseudointermedis [15]. Thus, a coa gene in CoNS with the newly described coa primers may be the result of such transfer. Coagulase activity in the current study may also be related to another gene such as the one described in $S$. chromogenes that shares $41 \%$ identity with the predicted coagulase gene of the S. pseudintermedius [15].

In this study, non-S. aureus stains able to clot plasma (19/19 S. chromogenes, 3/3 S. agnetis, 1/1 S. cohnii and 1/1 S. xylosus) were also Sa442 positive. This is the first report of false positive reactions with these species; however, further stains/herds should be tested to know whether these findings can be generalized. When the sequences of the Sa442 primers [4] were compared with the available genome of $S$. chromogenes MU 970 strain (NZ_JMJF00000000.1), no significant homology was detected; however, this draft whole shotgun sequence could be missing the region containing Sa442 sequences. Apart from having been established as unique for $S$. aureus, the Sa442 fragment has not been further characterized [18]. As well, Klaassen et al. [18] and Heilmann et al. [19] have reported false negative results with the Sa442 test and the nuc PCR is subject to strain variation [6].

Latex agglutination tests may also be problematic. In previous studies, false positive results have been observed at relatively low frequencies (e.g., 7.9\% [20] and 9.3\% [21]). The greater false positive reaction in this study (20\%) may have been related to the population structure and/or the relatively small sample size.

Given the impact that $S$. aureus can have on both human and animal health, its diagnosis is important [22, 23]. Misidentifying more benign Staphylococcus species as $S$. aureus, though arguably less serious, is not without significant economic consequences. In the current study, the eight $S$. aureus strains (as identified by MALDI-TOF/16S rRNA sequencing) were positive with our novel $S$. aureusspecific $c y d B$ PCR test while no amplification was observed with the Sa442 and plasma clotting-positive S. chromogenes $(\mathrm{n}=19)$, S. agnetis $(\mathrm{n}=3)$, S. xylosus $(\mathrm{n}=1)$ or $S$. cohnii $(\mathrm{n}=1)$ strains tested. Also, it might be noted that $S$. caprae, S. hyicus, S. hominis, S. epidermidis, S. haemolyticus, S. warneri, S. equorum, S. sciuri, and S. pasteuri were negative in the $S$. aureus-specific cydB real-time PCR test in a complementary study [13] (Table 2).

\section{Conclusions}

In summary, a significant number of CoNS strains could clot rabbit plasma and were positive for the Sa442 PCR test and so, could be misclassified as $S$. aureus. The bases of these phenotypes remain to be determined, but they could be the result of horizontal gene transfer or to the fact that these species are less homogenous than previously thought. On the other hand, MALDI-TOF and a species-specific real-time PCR test for the $c y d B$ gene may permit accurate identification of CoNS.

\section{Limitations}

This study used samples from one buffalo herd which limits the generalisation of the results. In addition, it was beyond the scope of this study to determine the basis of the abnormal coagulase positive phenotype or to determine if there had been horizontal gene transfer to coagulase negative Staphylococcus strains.

\section{Additional files}

Additional file 1: Fig. S1. S. aureus coagulase gene (coa) alignment using CLC Sequence View 7 software.

Additional file 2: Fig. S2. Alignment using CLC Sequence View 7 software of the $c y d B$ gene of 18 closely related Staphylococcus spp. in this study. 


\section{Abbreviations}

CoNS: coagulase negative Staphylococcus; MALDI-TOF MS: Matrix-Assisted Laser Desorption Ionization-Time of Flight Mass Spectrometry (MALDI-TOF MS); qPCR: real-time quantitative PCR; PCR: polymerase chain reaction; CoPS: coagulase positive Staphylococcus.

\section{Authors' contributions}

CCA, LLP and GAS developed the proposal, collected the samples in the field, did the laboratory work and drafted the manuscript. DS, FAA, JMP and JIM corrected the proposal, supervised the sample collection and laboratory work, analyzed the data, interpreted the results and provided technical advice and critically reviewed the manuscript. All authors read and approved the final manuscript.

\section{Author details}

${ }^{1}$ Agriculture and Livestock Microbiology Graduation Program, Department of Veterinary Pathology, São Paulo State University (Unesp), School of Agricultural and Veterinarian Sciences, Jaboticabal, Brazil. ${ }^{2}$ Department of Veterinary Preventive Medicine and Animal Reproduction, São Paulo State University (Unesp), School of Agricultural and Veterinarian Sciences, Jaboticabal, Brazil. ${ }^{3}$ Department of Pathobiology, University of Guelph, 50 Stone Rd. East, Guelph, ON N1G 2W1, Canada. ${ }^{4}$ Animal Health Laboratory, University of Guelph, Post Office 3612, Guelph, ON N1H 6R8, Canada. ${ }^{5}$ Department of Technology, São Paulo State University (Unesp), School of Agricultural and Veterinarian Sciences, Jaboticabal, Brazil.

\section{Acknowledgements}

Our thanks to Dr. David Heinrichs (University of Western Ontario) for the kind gift of S. aureus strains COL, NewMan, MW2, and Mu50.

\section{Competing interests}

The authors declare that they have no competing interests.

\section{Availability of data and materials}

The datasets generated during the current study are available from the corresponding author on reasonable request.

\section{Consent for publication}

Not applicable.

\section{Ethics approval and consent to participate}

The study was approved by the Ethics Committee on Animal Use (CEUA) of the School of Agricultural and Veterinarian Sciences, Jaboticabal_FCAV/ UNESP/Jaboticabal Campus_Brazil (Protocol Number 013737/13). Dairy farm owner have given verbal consent to use the animals in this work. Farm workers have also given verbal consent to participate in this work.

\section{Funding}

This work was conducted during a scholarship supported by the International Cooperation Program CAPES/COFECUB at the University of Guelph and financed by CAPES-Brazilian Federal Agency for Support and Evaluation of Graduate Education within the Ministry of Education of Brazil.

\section{Publisher's Note}

Springer Nature remains neutral with regard to jurisdictional claims in published maps and institutional affiliations.

Received: 26 March 2018 Accepted: 21 May 2018

Published online: 30 May 2018

\section{References}

1. Camargo G de, Aspilcueta-Borquis R, Fortes M, Porto-Neto R, Cardoso $D$, Santos D, et al. Prospecting major genes in dairy buffaloes. BMC Genomics. 2015;16:872. http://www.scopus.com/inward/recor d.url?eid=2-s2.0-84945538612\&partnerlD=tZOtx3y1\%5Cnhttp:// www.scopus.com/inward/record.url?eid=2-s2.0-84945538612\&partn

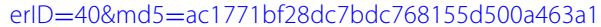

2. Zaitoun AMA. Clinical mastitis caused by Staphylococcus aureus in dairy buffaloes. Assiut Vet Med J. 2008;54:289-310.

3. Hamed MI, Zaitoun AMA. Prevalence of Staphylococcus aureus subclinical mastitis in dairy buffaloes farms. Int J Livest Res. 2014;4:21-8.

4. Martineau F, Picard FJ, Roy PH, Ouellette M, Bergeron MG. Species-specific and ubiquitous-DNA-based assays for rapid identification of Staphylococcus aureus. J Clin Microbiol Am Soc Microbiol. 1998;36:618-23.

5. Stutz K, Stephan R, Tasara T. SpA, ClfA, and FnbA genetic variations lead to Staphaurex test-negative phenotypes in bovine mastitis Staphylococcus aureus isolates. J Clin Microbiol. 2011;49:638-46.

6. Hoegh SV, Skov MN, Boye K, Worning P, Jensen TG, Kemp M. Variations in the Staphylococcus aureus-specific nuc gene can potentially lead to misidentification of meticillin-susceptible and -resistant S. aureus. J Med Microbiol. 2014;63:1020-2.

7. Radostits OM, Gay CC, Hinchcliff KW, Constable PD. Diseases of the mammary gland. Vet Med-A Textbook of Diseases of Cattle, Horses, Sheep, Pigs, Goats. 2007. p. 673-763.

8. Schalm OW, Noorlander DO. Experiments and observations leading to development of the California mastitis test. J Am Vet Med Assoc. 1957:130:199-204.

9. Silva WP, Destro MT, Landgraf M, Franco BDGM. Biochemical characteristics of typical and atypical Staphylococcus aureus in mastitic milk and environmental samples of Brazilian dairy farms. Brazilian J Microbiol. 2000;31:103-6. http://www.scielo.br/scielo.php?script=sci_artte $x t \& p i d=\$ 1517-83822000000200008 \& \operatorname{lng}=e n \& n r m=i s o \& t \operatorname{lng}=e n$.

10. Swanson JKM, Petran LR, Hanlin JH. Culture methods for enumeration of microorganisms. Compendium of methods for the microbiological examination of foods. 4th ed. Washington, DC: American Public Health Association; 2001. p. 53-62.

11. Capurro A, Aspán A, Unnerstad HE, Waller KP, Artursson K. Identification of potential sources of Staphylococcus aureus in herds with mastitis problems. J Dairy Sci. 2010;93:180-91.

12. Kuramae-Izioka EE. A rapid, easy and high yield protocol for total genomic DNA isolation of Colletotrichum gloeosporioides and Fusarium oxysporum. Unimar. 1997;19:683-9.

13. Pizauro LJL, de Almeida CC, Soltes GA, Slavic D, Rossi-Junior OD, de Ávila FA, et al. Species level identification of coagulase negative Staphylococcus spp. from buffalo using Matrix-Assisted Laser Desorption Ionization-Time of Flight Mass Spectrometry and $c y d B$ real-time quantitative PCR. Vet Microbiol. 2017;204:8-14. https://doi.org/10.1016/j.vetmic.2017.03.036.

14. Walker J, Borrow R, Edwards-Jones V, Oppenheim BA, Fox AJ. Epidemiological characterization of methicillin-resistant Staphylococcus aureus isolated in the North West of England by protein A (spa) and coagulase (coa) gene polymorphisms. Epidemiol Infect. 1998;121:507-14.

15. dos Santos DC, Lange CC, Avellar-Costa P, dos Santos KRN, Brito MAVP, Giambiagi-deMarval M. Staphylococcus chromogenes, a coagulasenegative Staphylococcus species that can clot plasma. J Clin Microbiol. 2016;54:1372-5.

16. Viana D, Blanco J, Tormo-Más MÁ, Selva L, Guinane CM, Baselga R, et al. Adaptation of Staphylococcus aureus to ruminant and equine hosts involves SaPl-carried variants of von Willebrand factor-binding protein. Mol Microbiol. 2010;77:1583-94.

17. McCarthy AJ, Loeffler A, Witney AA, Gould KA, Lloyd DH, Lindsay JA Extensive horizontal gene transfer during Staphylococcus aureus cocolonization in vivo. Genome Biol Evol. 2014;6:2697-708.

18. Klaassen CHW, De Valk HA, Horrevorts AM. Clinical Staphylococcus aureus isolate negative for the Sa442 fragment. J Clin Microbiol. 2003;41:4493.

19. Heilmann F, Van Der Zanden A, Reubsaet F, Wannet W. Identification of 2,600 clinical methicillin-resistant Staphylococcus aureus strains in the Netherlands yielded sporadic cases of strains negative for the speciesspecific Sa442 gene fragment. J Clin Microbiol. 2004;42:2350.

20. Idelevich EA, Walther T, Molinaro S, Li X, Xia G, Wieser A, et al. Bacteriophage-based latex agglutination test for rapid identification of Staphylococcus aureus. J Clin Microbiol. 2014:52:3394-8.

21. Bes LE, Etienne J, Zbinden R. International multicenter evaluation of latex agglutination tests for identification of Staphylococcus aureus. J Clin Microbiol. 2001;39:86-9. 
22. Pantosti A. Methicillin-resistant Staphylococcus aureus associated with animals and its relevance to human health. Front Microbiol. 2012:3:127.
23. Cheng AG, McAdow M, Kim HK, Bae T, Missiakas DM, Schneewind O. Contribution of coagulases towards Staphylococcus aureus disease and protective immunity. PLoS Pathog. 2010;6:19-20.

- fast, convenient online submission

- thorough peer review by experienced researchers in your field

- rapid publication on acceptance

- support for research data, including large and complex data types

- gold Open Access which fosters wider collaboration and increased citations

- maximum visibility for your research: over 100M website views per year

At BMC, research is always in progress.

Learn more biomedcentral.com/submissions 